\title{
Capsule Endoscopy in the Diagnosis of Eosinophilic Enteritis
}

\author{
Mafalda Sousa Rolando Pinho Luísa Proença \\ Gastrenterology Department, Centro Hospitalar de Vila Nova de Gaia e Espinho, Vila Nova de Gaia, Portugal
}

\section{Keywords}

Capsule endoscopy · Eosinophilic enteritis · Nonspecific findings

\section{Cápsula endoscópica no diagnóstico de enterite eosinofílica}

\section{Palavras Chave}

Cápsula endoscópica · Enterite eosinofílica · Achados inespecíficos

A 45-year-old female patient with allergic rhinitis without medication was referred for evaluation for suspected Crohn's disease in 2004. She presented with epigastralgia, dyspepsia, and iron deficiency anemia. Upper digestive endoscopy showed multiple erosions in the 2nd and 3rd duodenal portions; ileocolonoscopy was normal, and capsule endoscopy revealed 10 aphtoid erosions in the duodenum, jejunum, and ileum. Peripheral eosinophilia and elevated serum IgE were absent, and antitransglutaminase and stool for ova and parasites were negative. Surveillance without treatment was recommended, and the patient was lost to follow-up until 2017 when capsule endoscopy was repeated and revealed

\section{KARGER}

E-Mail karger@karger.com www.karger.com/pjg
(C) 2018 Sociedade Portuguesa de Gastrenterologia

Published by S. Karger AG, Basel

Karger

Open access

This article is licensed under the Creative Commons AttributionNonCommercial-NoDerivatives 4.0 International License (CC BYNC-ND) (http://www.karger.com/Services/OpenAccessLicense). Usage and distribution for commercial purposes as well as any distribution of modified material requires written permission. several focal areas of mucosal congestion, villous atrophy and pleomorphic denudation, and wide superficial erosions in the duodenum distal to the second portion (Fig. 1). Based on these findings, the patient underwent balloon-assisted enteroscopy (Fig. 2) to obtain histological material, which revealed a small intestinal mucosa with loss of the normal villous architecture secondary to chorion expansion by chronic inflammatory infiltrate, with the participation of numerous eosinophils with variable intensity, in some areas $>50$ eosinophils per large magnification field. The patient was referred to the immunoallergology department and started an empirical elimination diet with improvement of the abdominal symptoms.

Eosinophilic enteritis is a rare inflammatory disease with indefinite pathogenesis that is based on eosinophilic infiltration of the gastrointestinal tract and should be considered in the differential diagnosis of unexplained gastrointestinal symptoms. Since capsule endoscopy can visualize the entire small bowel, it is useful in the diagnosis, contributing to the localization of the lesions for biopsy [1]. Nevertheless, the findings in capsule endoscopy are nonspecific and difficult to differentiate from other entities and can include erythema, whitish specks, focal erosions, ulcerations, thickening of the folds, polyps, nodules, and friability $[2,3]$. 
1

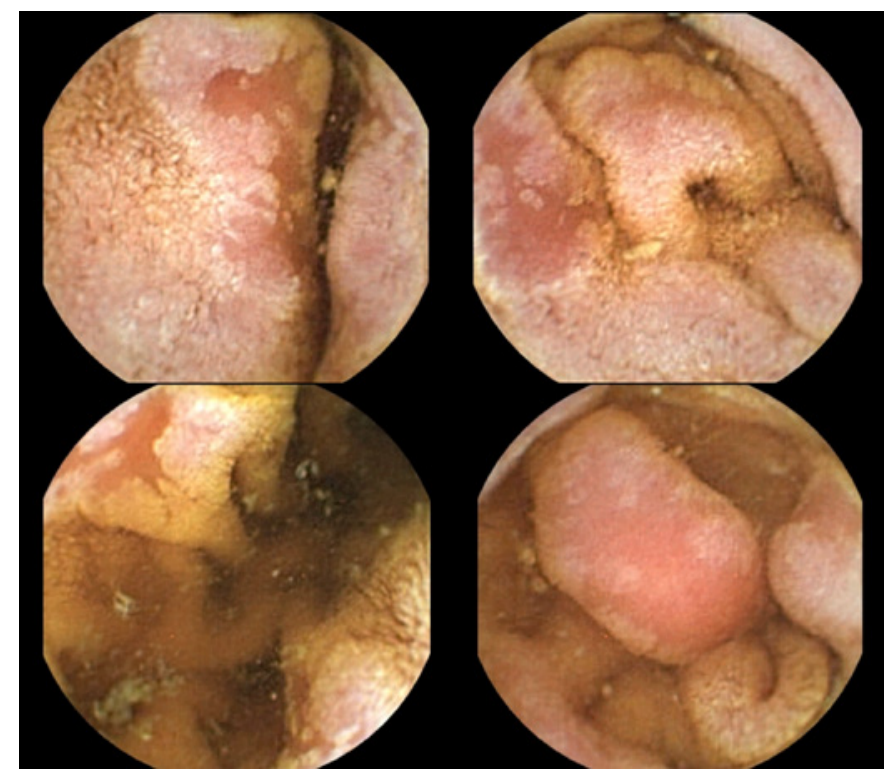

Statement of Ethics

An informed patient consent was obtained for the publication of the case details.

\section{Disclosure Statement}

The authors have no financial support or competing interests to disclose.

\section{2}

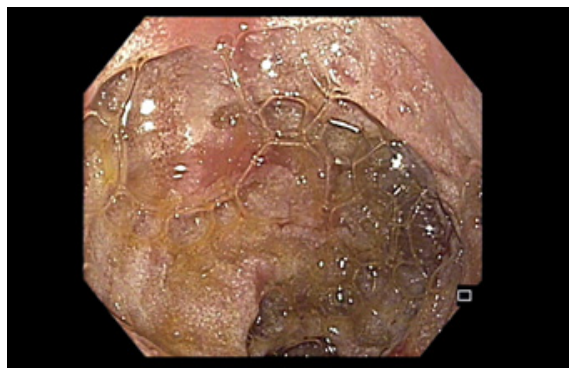

Fig. 1. Capsule endoscopy findings revealing several focal areas of mucosal congestion, villous atrophy and pleomorphic denudation, and wide superficial erosions.

Fig. 2. Balloon-assisted enteroscopy image showing focal areas of villous atrophy and pleomorphic denudation.

References

1 Kim N, Kim JW, Hwang JH, Lee DH, Lee HS Lee $\mathrm{KH}$, et al. Visualization of jejunal bleeding by capsule endoscopy in a case of eosinophilic enteritis. Korean J Intern Med. 2005 Mar; 20(1):63-7.

2 Nguyen N, Kramer RE, Friedlander JA. Videocapsule Endoscopy Identifies Small Bowel Lesions in Patients With Eosinophilic Enteritis. Clin Gastroenterol Hepatol. 2018 Jun; 16(6):e64-5.

3 Okuda K, Daimon Y, Iwase T, Mitsufuji S. Novel findings of capsule endoscopy and double-balloon enteroscopy in a case of eosinophilic gastroenteritis. Clin J Gastroenterol. 2013 Feb;6(1):16-9. 